\title{
Amifostine Anhydrous
}

National Cancer Institute

\section{Source}

National Cancer Institute. Amifostine Anhydrous. NCI Thesaurus. Code C66724.

A phosphorylated aminosulfhydryl compound with cytoprotective activity. Amifostine is dephosphorylated by alkaline phosphatase to an active free sulfhydryl (thiol) metabolite in the body. The thiol metabolite binds to and detoxifies cytotoxic platinum-containing metabolites of cisplatin and scavenges free radicals induced by cisplatin and ionizing radiation. The elevated activity of this agent in normal tissues results from both the relative abundance of alkaline phosphatase in normal tissues and the greater vascularity of normal tissues compared to tumor tissues. 